\title{
Student and Teacher Programs: For the Future of our Professions!
}

ISSN: 2578-0255

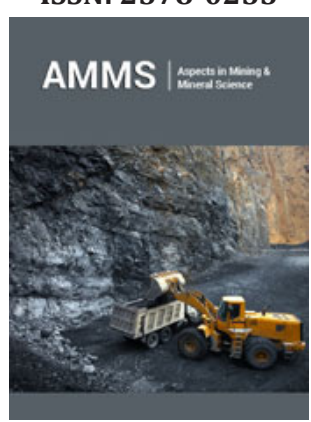

*Corresponding author: Thomas Stoebe, Professor Emeritus, University of Washington, Seattle WA, USA

Submission: 些 January 19, 2021

Published: 監January 27, 2021

Volume 6 - Issue 2

How to cite this article: Thomas Stoebe, Student and Teacher Programs: For the Future of our Professions!. Aspects Min Miner Sci. 6(2). AMMS. 000631. 2021. DOI: 10.31031/AMMS.2021.06.000631

Copyright@ Thomas Stoebe, This article is distributed under the terms of the Creative Commons Attribution 4.0 International License, which permits unrestricted use and redistribution provided that the original author and source are credited.

\section{Thomas Stoebe*}

Professor Emeritus, University of Washington, USA

\section{Opinion}

As professionals in the minerals sciences industries, one of our responsibilities is to work with students to enhance and promulgate our professions into the future. Part of this is for our professional organizations to develop programs that will help younger students to understand the glory of science and the practical importance of its applications. Students, as they grow up, play and experiment with Legos, skateboards, cell phones and other practical, real-world devices that are applications of science and technology, without thinking about the origin of the technology involved. I have been impressed with one application of this principle: programs developed by the ASM Materials Education Foundation, www.asmfoundation.org. This group provides summer and academic year programs for students related to applications in the mineral, metals and materials industries, often involving professionals from industry who provide real problems for students to solve. This program typically draws the very best and brightest students at the high school level and promotes their imaginations to new areas and helps then focus on further study in the sciences and engineering. These programs are held in locations across the US, hosted by colleges or local professional chapters or groups.

These programs are not just for the students. The ASM foundation provides hand-on curricula and lab experiments in applied sciences for teachers at the middle and high school levels through a summer camp program, held throughout the country. This is followed by weekly webinars to help and encourage teachers - how to do specific experiment, where to find help, etc. This program also provides grants to teachers so they can develop their own applied science exercises, along with design competitions and college scholarships for students! And the amazing part of this is that the programs for students and for teachers are offered at no cost to the participant - with many of the needed lab supplies etc., also provided. They do these using donations from professional engineers, technologists and scientists like you and me. A funding organization that promotes learning for students and teachers is the US National Science Foundation's Advanced Technological Education program, which provides grants to colleges and universities for specific projects. One such project, with which I am working, is the Materials Education Digital Library, www.materialseducation.org, offering peer-reviewed activities and experiments for teachers and students. There are other organizations and some companies that provide parts of these types of programs, but few coordinated efforts are currently available among our professional organization. Let us all talk with our own professional groups and help them understand the importance of these types of activities and help them to develop similar activities as part of our professional responsibilities to the future of our professions! 